\title{
Analisis Kemampuan Berpikir Kreatif Matematis Siswa Dalam Menyelesaikan Masalah Sistem Persamaan Linear Tiga Variabel
}

\author{
Ita Triyani ${ }^{1}$, Ervin Azhar ${ }^{2}$ \\ 1,2 Pendidikan Matematika, Fakultas Keguruan dan Ilmu Pendidikan, Universitas Muhammadiyah Prof Dr. Hamka, \\ J1. Tanah Merdeka No. 20, Rambutan, Jakarta Timur, Indonesia \\ itatriyani7@gmail.com
}

\begin{abstract}
The ability to think creatively is the ability to find many ways or alternative answers to solve a problem. The indicators of creative thinking skills used are fluency, flexibility, and novelty. The purpose of this study was to determine how far the students' mathematical creative thinking ability in solving the problem of a three-variable system of linear equations. This type of research is descriptive qualitative research. This research was conducted at SMA Negeri 15 Jakarta. The subject of this research is class X IPA 3. The instrument used is a test of creative thinking skills in the form of a three-variable system of equations material. The results of this study were that of the three that were achieved only by more in-depth investigation and interviews, there was one student who had three aspects of creative thinking skills according to silver and of the 22 students who took the test and after completing the results the answer was creative there were 12 people who had low thinking skills. So, it can be said that the ability to think creatively is low.
\end{abstract}

Keywords: Mathematical Creative Thinking Ability, SPLTV

\begin{abstract}
Abstrak
Kemampuan berpikir kreatif adalah kemampuan menemukan banyak cara atau alternatif jawaban untuk menyelesaikan suatu permasalahan. Indikator kemampuan berpikir kreatif yang digunakan adalah kefasihan, fleksibilitas dan kebaruan. Tujuan penelitian ini adalah untuk mengetahui seberapa jauh kemampuan berpikir kreatif matematis siswa dalam menyelesaikan masalah sistem persamaan linear tiga variabel. Jenis penelitian ini adalah penelitian kualitatif deskriptif. Penelitian ini dilaksanakan di SMA Negeri 15 Jakarta. Subjek penelitian ini adalah kelas X IPA 3. Instrument yang digunakan adalah berupa tes kemampuan berpikir kreatif yang berbentuk soal uraian pada materi sistem persamaan linear tiga variabel. Hasil dari penelitian ini adalah dari ketiga siswa yang diteliti dan diwawancarai lebih mendalam hanya ada satu siswa yang memenuhi ketiga aspek kemampuan berpikir kreatif menurut silver dan dari 22 siswa yang mengerjakan tes dan setelah diteliti hasil jawabannya ada 12 orang yang memiliki kemampuan berpikir kreatif rendah. Maka dapat disimpulkan bahwa kemampuan berpikir kreatif siswa tergolong rendah.
\end{abstract}

Kata kunci: Kemampuan Berpikir Kreatif Matematis, SPLTV

Copyright (c) 2021 Ita Triyani, Ervin Azhar

$\triangle$ Corresponding author: Ita Triyani

Email Address: itatriyani7@gmail.com ((Jl. Tanah Merdeka No 20, Rambutan, Jakarta Timur)

Received 27 July 2021, Accepted 31 August 2021, Published 14 October 2021

\section{PENDAHULUAN}

Pendidikan adalah hal yang sangat penting untuk menciptakan sumber daya manusia yang berkualitas. Sebagaimana tercantum dalam Undang-Undang Republik Indonesia Nomor 20 Tahun 2003 tentang Sistem Pendidikan Nasional, menyatakan bahwa pendidikan nasional berfungsi mengembangkan kemampuan dan membentuk watak serta peradaban bangsa yang bermartabat dalam rangka mencerdaskan kehidupan bangsa, bertujuan untuk berkembangnya potensi peserta didik agar menjadi manusia yang beriman dan bertakwa kepada Tuhan Yang Maha Esa, berakhlak mulia, sehat, berilmu, cakap, kreatif, mandiri dan menjadi warga negara yang demokratis serta bertanggung jawab (Rifa’i dkk, 2020). Menurut U.S., Supardi pendidikan adalah suatu usaha atau kegiatan yang dijalankan dengan sengaja, teratur dan berencana dengan maksud mengubah atau mengembangkan perilaku yang 
diinginkan. Oleh karena itu, pendidikan sangat penting karena dengan adanya pendidikan, peserta didik dapat mengembangkan potensi yang dimilikinya dan peserta didik dapat mengubah atau mengembangkan perilakunya menjadi lebih baik. Pendidikan juga merupakan kunci utama bagi suatu negara dalam persaingan global. Dengan adanya Pendidikan yang baik pada suatu negara, maka negara tersebut dapat dikatakan lebih unggul atau lebih baik.

Salah satu mata pelajaran yang wajib dalam Pendidikan formal adalah matematika. Menurut Rifa'i dkk (2020) matematika merupakan salah satu ilmu yang mendasari perkembangan ilmu dan teknologi maka itu matematika berperan penting dalam pembelajaran. Menurut Noer dalam Mulyaningsih \& Ratu (2018) Matematika memiliki potensi untuk meningkatkan kemampuan berpikir, berargumentasi, memberikan kontribusi dalam penyelesaian masalah sehari-hari dan potensi tersebut dapat terwujud bila pembelajaran matematika menekankan pada aspek peningkatan kemampuan berpikir tingkat tinggi yang mengharuskan siswa memanipulasi informasi serta ide-ide dalam cara tertentu yang memberikan mereka pengertian dan implikasi baru. Kemampuan berpikir tingkat tinggi salah satunya adalah berpikir kreatif. Dalam pembelajaran matematika diperlukan kemampuan berpikir kreatif.

Menurut Siswono dalam Prianggono (2010) berpikir kreatif merupakan suatu proses yang digunakan ketika kita mendatangkan/ memunculkan suatu ide baru. Sementara menurut Andiyana dkk (2018) berpikir kreatif adalah kemampuan siswa menarik kesimpulan dari suatu permasalahan matematika melalui langkah langkah yang tidak rutin. Sedangkan menurut Isaksen dan Treffinger dalam Fitriarosah (2016) mendefinisikan berpikir kreatif sebagai proses konstruksi ide yang menekankan pada aspek kelancaran, keluwesan, kebaruan, dan keterincian. Menurut Muthaharah dkk (2018) kemampuan berpikir kreatif dalam matematika mengarah pada kemampuan berpikir kreatif matematis. Menurut Amidi \& Zahid (2016) kemampuan berpikir kreatif matematis yang dimaksud adalah kemampuan mengemukakan ide-ide dalam menyelesaikan soal-soal matematika. Livne dalam Amidi \& Zahid (2016) berpendapat bahwa berpikir kreatif matematis merujuk pada kemampuan untuk menghasilkan solusi bervariasi yang bersifat baru terhadap masalah matematika yang bersifat terbuka. Dari definisi diatas dapat disimpulkan bahwa berpikir kreatif matematis adalah kemampuan menghasilkan solusi atau mengemukakan ide-ide yang bervariasi dalam menyelesaikan suatu permasalahan matematika. Siswa sangat membutuhkan kemampuan berpikir kreatif matematis dalam pembelajaran matematika karena dapat memudahkan siswa dalam menyelesaikan permasalahan matematika. Menurut Muthaharah dkk (2018) kemampuan berpikir kreatif matematis dapat dikembangkan dalam proses pembelajaran dan tidak dapat terjadi dengan sendirinya. Menurut Huliatunisa dkk (2019) manfaat dari kemampuan berpikir kreatif matematis akan memunculkan ide ide baru atau gagasan spontan dan terkadang tanpa direncanakan sebelumnya dalam pemikiran individu, sehingga akan mendatangkan pemikiran dan jawaban yang kreatif dan bervariasi pada setiap persoalan yang dihadapi. Pada penelitian ini, peneliti menggunakan indikator kemampuan berpikir kreatif menurut silver. Indikator menurut Silver (1997) untuk mengidentifikasi dan menganalisis tingkat berpikir kreatif seseorang dalam pemecahan masalah 
dan pengajuan masalah umumnya digunakan tiga aspek kreatifitas yang merupakan tiga kunci komponen kreativitas dalam Torrance Test of Creative Thinking (TTCT) yaitu aspek kefasihan (fluency), aspek fleksibilitas (flexibility) dan aspek kebaruan (originality).

Kemampuan berpikir kreatif adalah kemampuan menemukan banyak cara atau alternatif jawaban untuk menyelesaikan suatu permasalahan. Oleh karena itu kemampuan berpikir kreatif matematis sangat penting dimiliki oleh setiap siswa. Namun berdasarkan hasil penelitian yang dilakukan oleh Pratiwi dkk (2018) menunjukan bahwa kemampuan berpikir kreatif matematis siswa masih tergolong rendah. Selain itu, saat ini dalam pembelajaran matematika kemampuan berpikir kreatif kurang diperhatikan oleh guru. Beberapa pembelajaran matematika cenderung hanya memberikan soalsoal pada buku teks yang hanya memiliki satu jawaban dan saat pembelajaran juga lebih menekankan pada pemberian rumus dan penggunaan rumus secara langsung dalam menyelesaikan soal. Hal tersebut membuat siswa menjadi cenderung menghafal rumus dan menyelesaikan soal sesuai dengan yang guru contohkan. Dalam pembelajaran matematika, siswa sering dihadapkan pada suatu masalah yang rumit. Oleh karena itu kemampuan berpikir kreatif sangat diperlukan siswa dalam menyelesaikan masalah yang semakin kompleks.

Salah satu materi dalam matematika adalah sistem persamaan linear tiga variabel (SPLTV). Materi sistem persamaan linear tiga variabel biasanya mulai diajarkan pada jenjang SMA di kelas X. Menurut Cardo A.P dkk (2020) Standar kompetensi yang harus dikuasai oleh siswa dalam mempelajari sistem persamaan linear tiga variabel, yaitu menyusun SPLTV dari masalah kontekstual dan menyelesaikan masalah kontekstual yang berkaitan dengan SPLTV. Pembelajaran SPLTV diawali dengan mengenali bentuk umum dari SPLTV itu sendiri. Menurut Patra \& Pujiastuti (2020) Materi SPLTV dinilai memiliki tingkatan yang lumayan sulit, karena rata-rata materi ini mengambil contoh pada kehidupan sehari hari dan penyajian soal pada materi SPLTV dalam bentuk soal cerita. Penyajian soal dalam bentuk cerita inilah yang membuat materi sistem persamaan linear tiga variabel menjadi materi yang lumayan sulit. Berikut contoh soal materi SPLTV.

Tiga tukang cat bernama Joni, Deni, dan Ari biasanya bekerja secara bersama-sama. Mereka dapat mengecat bagian luar (eksterior) sebuah rumah dalam waktu 10 jam kerja. Deni dan Ari pernah bersama-sama mengecat rumah yang serupa dalam waktu 15 jam kerja. Suatu hari, ketiga tukang cat ini bekerja mengecat rumah serupa selama 4 jam kerja. Setelah itu, Ari pergi karena ada keperluan mendadak. Joni dan Doni memerlukan tambahan waktu 8 jam kerja lagi untuk menyelesaikan pengecatan rumah. Tentukan waktu yang dibutuhkan masing-masing tukang cat jika masing-masing bekerja sendirian (AN Saputra, 2020).

Pada penjelasan yang telah diuraikan diatas, peneliti tertarik untuk melakukan suatu penelitian dengan judul “Analisis Kemampuan Berpikir Kreatif Matematis Siswa Dalam Menyelesaikan Masalah Sistem Persamaan Linear Tiga Variabel". Salah satu penelitian yang relevan dengan penelitian ini adalah penelitian oleh Rachman \& Amelia dalam penelitiaan yang berjudul "Analisis Kemampuan Berpikir Kreatif Matematis Siswa SMA di Kabupaten Bandung Barat dalam Menyelesaikan Soal Pada Materi 
Trigonometri”. Dalam penelitian ini disimpulkan bahwa kemampuan berpikir kreatif matematis siswa SMA di kabupaten Bandung Barat pada materi trigonometri tergolong rendah. Pembaruan penelitian ini adalah materi yang digunakan pada penelitian merupakan materi Sistem Persamaan Linear Tiga Variabel (SPLTV) dan aspek kemampuan berpikir kreatif yang digunakan untuk meneliti adalah aspek kemampuan berpikir kreatif menurut Silver.

\section{METODE}

Dalam penelitian ini peneliti menggunakan metode penelitian kualitatif deskriptif. Instrument yang digunakan dalam pengambilan data berupa tes tertulis dengan materi sistem persamaan linear tiga variabel. Soal yang digunakan dalam penelitian dapat mengukur kemampuan berpikir kreatif siswa. Subjek penelitian ditentukan dengan menggunakan teknik purposive sampling. Penelitian ini dilaksanakan di SMA Negeri 15 Jakarta yang berlokasi di Jalan Agung Utara STS, Jakarta Utara. Subjek dalam penelitian ini adalah siswa kelas X IPA 3 di SMAN 15 Jakarta. Data di peroleh peneliti dari wawancara, dokumentasi dan pemberian soal kepada siswa kelas X IPA 3. Siswa yang diwawancarai oleh peneliti ada 3 orang yaitu satu siswa yang memiliki kemampuan berpikir kreatif tinggi, satu siswa yang memiliki kemampuan berpikir kreatif sedang dan satu siswa yang memiliki kemampuan berpikir kreatif rendah. Pemilihan ketiga siswa tersebut untuk dilakukan wawancara dengan melihat hasil tes tertulisnya. Teknik wawancara yang digunakan adalah teknik wawancara tidak terstruktur. Teknik analisis data dalam penelitian ini menggunakan tiga cara yaitu, reduksi data, penyajian data dan penarikan kesimpulan.

\section{HASIL DAN DISKUSI}

Peneliti telah menganalisis lebih dalam tentang kemampuan berpikir kreatif matematis siswa dari beberapa subjek berdasarkan tiga aspek kreativitas menurut silver, yaitu: aspek kefasihan (fluency), aspek fleksibilitas (flexibility) dan aspek kebaruan (originality). Dalam penelitian ini peneliti menggunakan kelas X MIPA 3 sebagai subjek penelitian. Subjek penelitian terdiri dari 22 orang yang menunjukkan bahwa ada 2 orang yang memiliki kemampuan berpikir kreatif tinggi, 8 orang memiliki kemampuan sedang dan 12 orang yang memiliki kemampuan rendah. Dari 22 orang tersebut peneliti akan memilih 3 orang siswa untuk di wawancara. Pemilihan ketiga siswa itu berdasarkan hasil tes yang dikerjakannya dan penilaian sesuai dengan ketiga aspek menurut Silver. Soal tes yang diberikan setiap siswa berbeda - beda.

Berikut hasil penelitian dari ketiga subjek yang telah mengerjakan soal uraian materi sistem persamaan linear tiga variabel dan telah di wawancarai, serta disajikan kembali soal sistem persamaan linear tiga variabel untuk memperjelas dalam menganalisis hasil pekerjaan subjek. Setiap siswa mendapatkan soal yang berbeda. 
Tabel 2. Soal - Soal SPLTV

\begin{abstract}
Soal S1
1. Dinda memiliki uang Rp. 40.000. Kemudian ia ingin membeli buku, pensil dan penghapus. Harga 1 buku Rp. 6.000, harga 1 pensil Rp. 2.500 dan harga 1 penghapus Rp. 1.000. Berapakah kemungkinan jumlah buku, pensil dan penghapus yang dapat Dinda beli sehingga uangnya habis. Minimal 2 kemungkinan!

2. Diketahui Dika 3 tahun lebih tua dari Siska, dan umur Siska 2 tahun lebih tua dari Ratih. Jumlah umur mereka adalah 46 tahun. Tentukan umur masing - masing, kemudian dari hasil jawaban mu buatlah pertanyaan dan berikan solusinya.

3. Dimas, Aisyah dan Sisil masing - masing memiliki sebuah pita dengan panjang yang berbeda. Jika diketahui selisih panjang pita Dimas dan Aisyah adalah $6 \mathrm{~cm}$. Sedangkan panjang pita Aisyah $3 \mathrm{~cm}$ lebih panjang dari pita Sisil. Tentukan panjang pita masing - masing dengan terlebih dahulu menentukan panjang pita seluruhnya!
\end{abstract}

\title{
Soal S2
}

1. Sinta memiliki uang Rp. 60.000 . Kemudian ia ingin membeli buku, pensil dan penghapus. Harga 1 buku Rp.8.000, harga 1 pensil Rp.4.000 dan harga 1 penghapus Rp.3.000. Berapakah kemungkinan jumlah buku, pensil dan penghapus yang dapat Sinta beli sehingga uangnya habis. Minimal 2 kemungkinan!

2. Diketahui Deri 6 tahun lebih tua dari Eli, dan umur Eli 4 tahun lebih tua dari Fika. Jumlah umur mereka adalah 80 tahun. Tentukan umur masing - masing, kemudian dari hasil jawaban mu buatlah pertanyaan dan berikan solusinya.

3. Saskia, Akbar dan Susi masing - masing memiliki sebuah pita dengan panjang yang berbeda. Jika diketahui selisih panjang pita Saskia dan Akbar adalah $3 \mathrm{~cm}$. Sedangkan panjang pita Akbar $2 \mathrm{~cm}$ lebih panjang dari pita Susi. Tentukan panjang pita masing - masing dengan terlebih dahulu menentukan panjang pita seluruhnya!

\section{Soal S3}

1. Tio memiliki uang Rp. 55.000. Kemudian ia ingin membeli buku, pensil dan penghapus. Harga 1 buku Rp. 9.000, harga 1 pensil Rp. 4.000 dan harga 1 penghapus Rp. 2.000 . Berapakah kemungkinan jumlah buku, pensil dan penghapus yang dapat Tio beli sehingga uangnya habis. Minimal 2 kemungkinan!

2. Diketahui Edho 5 tahun lebih tua dari Vita, dan umur Vita 2 tahun lebih tua dari Rara. Jumlah umur mereka adalah 40 tahun. Tentukan umur masing - masing, kemudian dari hasil jawaban mu buatlah pertanyaan dan berikan solusinya.

3. Putri, Meli dan Yana masing - masing memiliki sebuah pita dengan panjang yang berbeda. Jika diketahui selisih panjang pita Putri dan Meli adalah $8 \mathrm{~cm}$. Sedangkan panjang pita Meli $3 \mathrm{~cm}$ lebih panjang dari pita Yana. Tentukan panjang pita masing - masing dengan terlebih dahulu menentukan panjang pita seluruhnya!

Pada soal no 1, subjek diminta untuk menentukan kemungkinan kemungkinan dari suatu penyelesaian masalah. Untuk soal no 2, subjek dituntut untuk dapat menentukan umur masing - masing 
dan dari umur masing - masing yang sudah diketahui dibuat soal serta penyelesaiannya. Untuk soal no 3, subjek dituntut untuk dapat menentukan panjang pita masing - masing dengan terlebih dahulu menentukan panjang pita seluruhnya.

\section{Subjek pertama $\left(S_{1}\right)$}

Berdasarkan hasil pengamatan data yang diperoleh dari penelitian, berikut analisis data kemampuan berpikir kreatif $\left(S_{1}\right)$ dalam menyelesaikan masalah sistem persamaan linear tiga variabel. $S_{1}$ mendapatkan kode soal nomor 5.

\section{Jawaban nomor 1}

Berikut peneliti sajikan hasil pekerjaan $S_{1}$ dalam mengerjakan soal no 1 yaitu mencari kemungkinan jumlah barang yang dibeli sehingga uang habis.

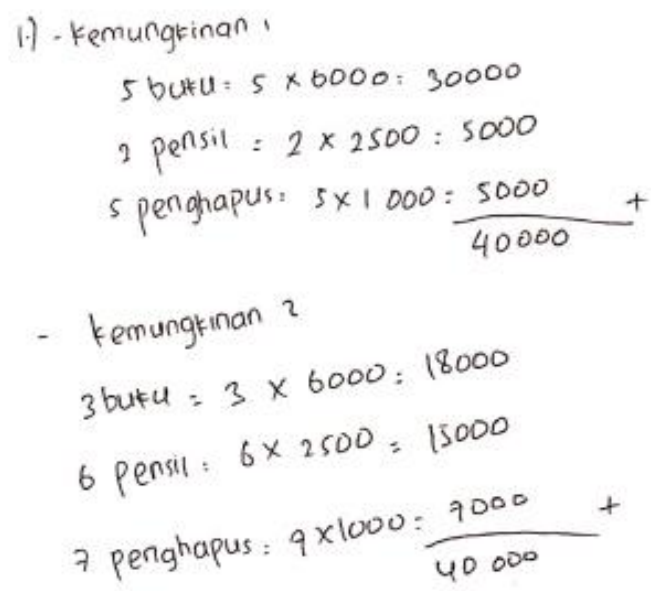

Gambar 1. Hasil pekerjaan $S_{1}$ soal nomor 1

Dari gambar diatas dapat diketahui bahwa $S_{1}$ memahami soal yang diberikan, hal itu terlihat dari cara $S_{1}$ menjawab soal. Dalam menjawab soal no 1 , untuk kemungkinan pertama $S_{1}$ menjawab dengan cara mengira - ngira jumlah buku, pensil dan penghapusnya. Lalu setelah itu jumlah buku, pensil dan penghapusnya dikali dengan harga masing - masing buku, pensil dan penghapus yang sudah diketahui disoal. Untuk kemungkinan kedua, $S_{1}$ menggunakan cara yang sama dengan cara perhitungan kemungkinan pertama. Dalam perhitungan hanya berbeda pada jumlah buku, pensil dan penghapusnya. Saat diwawancarai $S_{1}$ juga menjelaskan bahwa dalam menentukan jumlah buku, pensil dan penghapusnya ia menggunakan cara kira - kira. Berikut cuplikan wawancara antara $S_{1}$ dan peneliti. P: "Bisa tolong jelaskan bagaimana cara kamu menjawab no 1 ini?"

S: "Pertama saya cari dulu kak jumlah buku, pensil dan penghapusnya. Setelah itu jumlah buku, pensil dan penghapus yang sudah dicari tadi saya kalikan dengan harganya yang sudah diketahui disoal. Abis itu baru deh hasil kalinya dijumlah didapat hasilnya 40.000 sesuai dengan uang dinda yang diketahui disoal." P: "Oke, saya mau tanya kamu dapat jumlah buku, pensil dan penghapusnya itu dengan cara apa?" 


\section{S: "Oh itu saya kira - kira kak"}

Berdasarkan cuplikan wawancara diatas dapat diketahui bahwa $S_{1}$ memahami soal yang diberikan. Hal itu dapat dilihat dari cara $S_{1}$ menjawab pertanyaan, $S_{1}$ menjawab pertanyaan dengan cara mengira - ngira jumlah buku, pensil dan penghapusnya. Setelahh itu ia kalikan jumlah buku, pensil dan penghapusnya dengan harga yang telah diketahui disoal. $S_{1}$ juga mampu menjelaskan jawaban yang ia kerjakan dengan baik dan benar. $S_{1}$ juga mampu menemukan kemungkinan - kemungkinan lain dari jumlah buku, pensil dan penghapusnya. Hal ini menunjukkan bahwa $S_{1}$ memenuhi aspek kefasihan (fluency) dalam menyelesaikan soal yang diberikan oleh peneliti.

Berdasarkan hasil pekerjaan dan hasil wawancara dapat diketahui bahwa $S_{1}$ mampu memahami soal sehingga ia mampu menemukan kemungkinan jawaban lain. Selain itu jawaban yang $S_{1}$ berikan benar dan saat di wawancarai $S_{1}$ juga mampu menjelaskan jawabannya dengan lancar. Sehingga dapat dikatakan bahwa $S_{1}$ memenuhi aspek kefasihan (fluency).

\section{Jawaban nomor 2}

Berikut peneliti sajikan hasil pekerjaan $S_{1}$ dalam menyelesaikan soal no 2 yaitu menentukan umur masing - masing dari yang diketahui di soal lalu dari hasil jawaban subjek dibuat soal dan jawabannya.

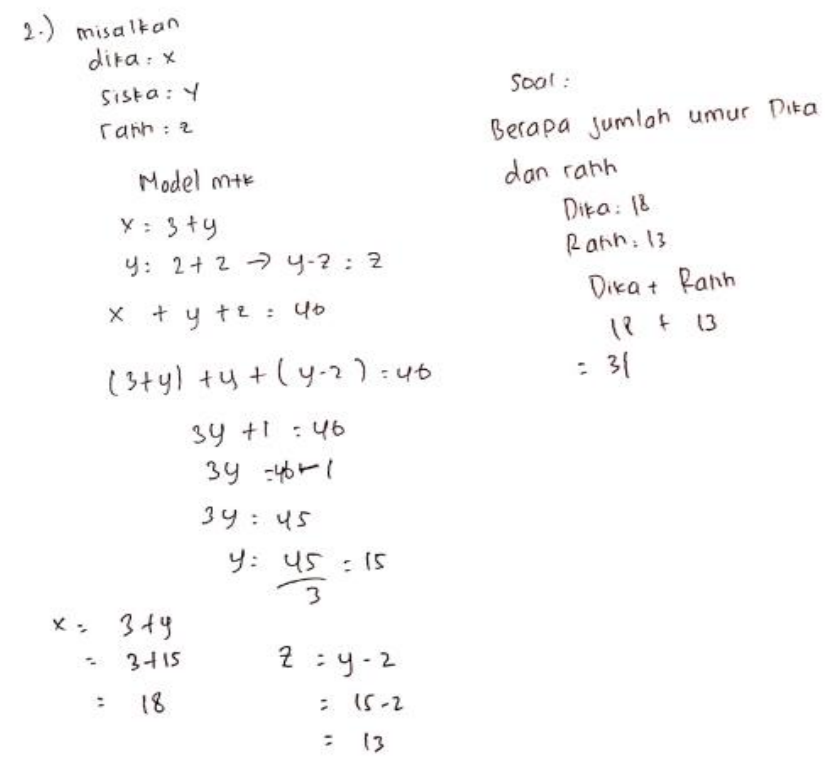

Gambar 2. Hasil pekerjaan $S_{1}$ soal nomor 2

Berdasarkan gambar diatas dapat diketahui bahwa $S_{1}$ mampu memahami soal yang diberikan hal itu dapat dilihat dari cara $S_{1}$ menjawab pertanyaan. Saat menjawab pertanyaan, pertama $S_{1}$ memisalkan nama - nama tokoh yang diketahui disoal menjadi x, y, dan z. Setelah itu $S_{1}$ membuat model matematikanya yang terdiri dari 3 persamaan, selanjutnya $S_{1}$ mensubstitusikan x dan y nya ke salah satu persamaan yang ia buat (dapat dilihat pada gambar 2) dan di dapatkan hasilnya $y=15$ seperti 
digambar. Setelah itu $S_{1}$ mencari x dan z, caranya yaitu mensubstitusikan nilai y ke persamaan x $=3+$ $\mathrm{y}$ dan $\mathrm{z}=\mathrm{y}-2$. Setelah disubstitusikan maka didapatkan hasil $\mathrm{x}=18$ dan $\mathrm{z}=13$. Soal yang dibuat $S_{1}$ berupa soal penjumlahan yang menurut $S_{1}$ itu merupakan soal yang mudah cara penyelesaiannya. Hal itu dijelaskan oleh $S_{1}$ saat ia di wawancara. Berikut cuplikan wawancaranya.

P: "Oke, untuk pertanyaannya kenapa kamu memilih pertanyaan seperti itu?"

S: "Menurut saya itu pertanyaan yang mudah di jawab kak."

Berdasarkan cuplikan wawancara diatas dapat diketahui bahwa $S_{1}$ mampu memahami soal yang diberikan. Hal itu terlihat dari cara $S_{1}$ menjawab pertanyaan yang diberikan, $S_{1}$ menjawab pertanyaan dengan cara substitusi seperti cara yang sudah $S_{1}$ jelaskan diatas. Untuk soalnya $S_{1}$ memilih soal penjumlahan umur antara umur dika dan ratih. Hal itu terlihat bahwa $S_{1}$ mampu menyelesaikan masalah dengan satu cara penyelesaian masalah kemudian dengan cara penyelesaian yang lain. Maka dapat di simpulkan bahwa $S_{1}$ memenuhi aspek fleksibilitas (flexibility).

Berdasarkan hasil pekerjaan dan hasil wawancara yang dilakukan maka dapat diketahui bahwa $S_{1}$ mampu memahami soal yang diberikan. Hal itu terlihat dari cara $S_{1}$ menjawab pertanyaan, ia mampu menjawab pertanyaan dengan satu cara penyelesaian kemudian dengan cara penyelesaian lain. Dengan begitu maka dapat diketahui bahwa $S_{1}$ memenuhi aspek fleksibilitas (flexibility).

\section{Jawaban nomor 3}

Berikut peneliti sajikan hasil pekerjaan $S_{1}$ dalam mengerjakan soal no 3 yaitu menentukan panjang pita masing masing yang di ketahui di soal dengan terlebih dahulu menentukan panjang pita seluruhnya.

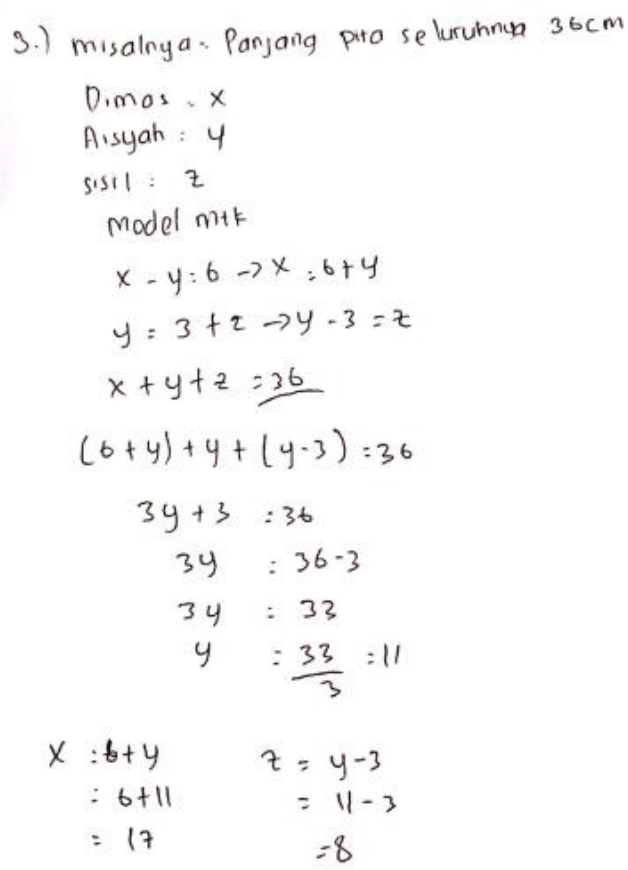

Gambar 3. Hasil pekerjaan $S_{1}$ soal no 3 
Berdasarkan gambar diatas dapat diketahui bahwa $S_{1}$ mampu memahami soal yang diberikan. Hal itu terlihat dari cara $S_{1}$ menjawab pertanyaan, cara yang digunakan $S_{1}$ yaitu pertama $S_{1}$ memisalkan panjang pita seluruhnya terlebih dahulu. Panjang pita yang dibuat $S_{1}$ adalah 36. Setelah itu $S_{1}$ memisalkan nama - nama tokoh yang diketahui disoal menjadi x, y, z. Berikutnya $S_{1}$ membuat model matematikanya yang terdiri dari tiga persamaan seperti di gambar hasil pekerjaan $S_{1}$. Berikutnya $S_{1}$ mensubstitusikan $\mathrm{x}$ dan $\mathrm{z}$ nya ke persamaan $\mathrm{x}+\mathrm{y}+\mathrm{z}=36$. Maka didapat hasil $\mathrm{y}=11$. Berikutnya $S_{1}$ mencari x dan z dengan cara substitusi. Saat diwawancarai $S_{1}$ juga menjelaskan hasil pekerjaan nya dengan lancar dan cara yang dipilih $S_{1}$ adalah cara substitusi. Berikut cuplikan wawancara antara $S_{1}$ dan peneliti.

P: "Oke, dari soal yang sudah kamu kerjakan. Apakah kamu pernah jumpai sebelumnya?"

S: "belum."

P: "Apakah soal seperti itu belum pernah di ajarkan oleh gurunya?"

S: "kayaknya sudah kak tapi mungkin saya lupa."

P: "Jadi jawaban kamu itu memang hasil pemikiran kamu sendiri?"

S: "Iya kak."

Berdasarkan hasil wawancara diatas dapat diketahui bahwa $S_{1}$ mampu memahami soal yang diberikan hal itu terlihat dari cara $S_{1}$ menjawab pertanyaan yang diberikan. Cara yang digunakan $S_{1}$ adalah cara substitusi. $S_{1}$ juga menjelaskan bahwa jawaban yang ia kerjakan adalah hasil pemikirannya sendiri. Hal ini terlihat bahwa $S_{1}$ memenuhi aspek kebaruan (originality).

Berdasarkan hasil pekerjaan dan hasil wawancara yang sudah dilakukan dapat diketahui bahwa $S_{1}$ mampu memahami soal yang diberikan oleh peneliti. Hal itu terlihat dari cara $S_{1}$ menjawab pertanyaan dan saat di wawancara $S_{1}$ juga menjelaskan bahwa hasil jawaban yang ia kerjakan adalah hasil pemikirannnya sendiri. Maka dapat disimpulkan bahwa $S_{1}$ memenuhi aspek kebaruan (originality).

\section{Subjek kedua $\left(S_{2}\right)$}

Berdasarkan hasil pengamatan data yang diperoleh dari penelitian, berikut analisis data kemampuan berpikir kreatif $\left(S_{2}\right)$ dalam menyelesaikan masalah sistem persamaan linear tiga variabel. Subjek $S_{2}$ ini mendapatkan kode soal nomor 11.

\section{Jawaban nomor 1}

Berikut peneliti sajikan hasil pekerjaan $S_{2}$ dalam mengerjakan pertanyaan nomor 1 yaitu mencari kemungkinan jumlah barang yang dibeli sehingga uang abis.

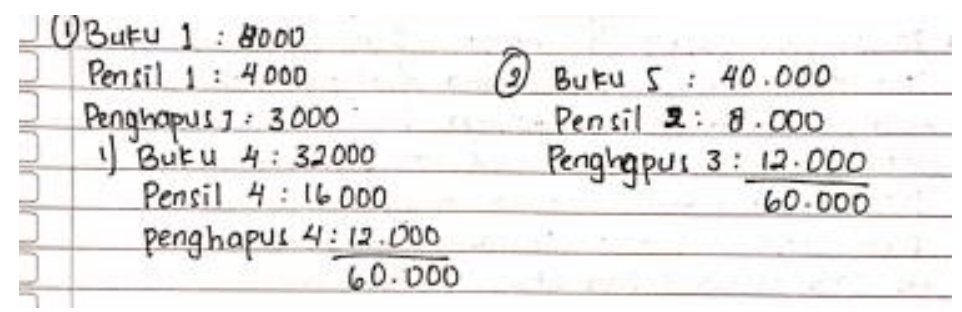

Gambar 4. Hasil pekerjaan $S_{2}$ soal nomor 1 
Dari gambar diatas dapat diketahui bahwa $S_{2}$ memahami soal yang diberikan oleh peneliti, karena terlihat dari jawaban yang $S_{2}$ kerjakan sudah benar. $S_{2}$ dapat menjawab no 1 untuk kemungkinan pertama dengan cara mencari jumlah buku, pensil dan penghapusnya terlebih dahulu setelah itu jumlah buku, pensil dan penghapusnya dikali dengan harga yang sudah diketahui di soal. Setelah itu $S_{2}$ menjumlahkan hasil kali antara jumlah buku dan harganya, jumlah pensil dan harganya, serta jumlah penghapus dan harganya. Untuk kemungkinan kedua $S_{2}$ menggunakan cara yang sama tapi dengan jumlah buku, pensil dan penghapus yang berbeda. Saat $S_{2}$ diwawancarai, $S_{2}$ menjelaskan bahwa untuk mendapatkan jumlah buku, pensil dan penghapusnya $S_{2}$ hanya dengan mengira - ngira jumlahnya sehingga didapatkan jumlah buku, pensil dan penghapus seperti yang $S_{2}$ jawab pada gambar. Berikut cuplikan hasil wawancara antara peneliti dengan $S_{2}$.

P: "Saya ingin bertanya, kamu mendapatkan 4 pensil, 4 buku dan lain lainya itu bagaimana?"

S: "Mengira ngira karena ini kan kemungkinan"

P: Menurut kamu ada cara lain ga, selain cara yang kamu gunakan ini?”,

S: "Hmm tidak ada sih bu yang saya tau."

P: "Tapi untuk jumlah buku, pensil dan penghapus lainnya, apa ada jawaban lain selain yang kamu jawab ini?"

\section{S: "Kemungkinan ada."}

Berdasarkan hasil cuplikan wawancara diatas dapat diketahui bahwa $S_{2}$ memahami soal yang diberikan. Hal tersebut terlihat dari cara $S_{2}$ menjawab pertanyaan dengan cara menentukan terlebih dahulu jumlah buku, pensil, dan penghapusnya. Setelah itu jumlah buku, pensil dan penghapusnya dikalikan dengan harga - harga yang sudah diketahui. $S_{2}$ juga mampu menemukan kemungkinan penyelesaian lain dalam menjawab soal dan $S_{2}$ mampu menjelaskan dengan lancar. Hal ini menunjukkan bahwa $S_{2}$ memenuhi aspek kefasihan (fluency) dalam menjawab pertanyaan yang diberikan oleh peneliti.

Berdasarkan hasil pekerjaan dan hasil wawancara yang dilakukan maka dapat diketahui bahwa $S_{2}$ mampu memahami soal yang diberikan sehingga $S_{2}$ mampu menemukan kemungkinan penyelesaian lain dalam menjawab soal. $S_{2}$ juga dapat menjawab soal dengan benar dan dapat menjelaskan jawabannya dengan lancar. Sehingga dapat dikatakan bahwa $S_{2}$ sudah memenuhi aspek kefasihan (fluency).

\section{Jawaban nomor 2}

Berikut peneliti sajikan hasil pekerjaan $S_{2}$ dalam mengerjakan pertanyaan nomor 2 yaitu menentukan umur masing - masing dari yang diketahui di soal lalu dari hasil jawaban subjek dibuat soal dan jawabannya. 


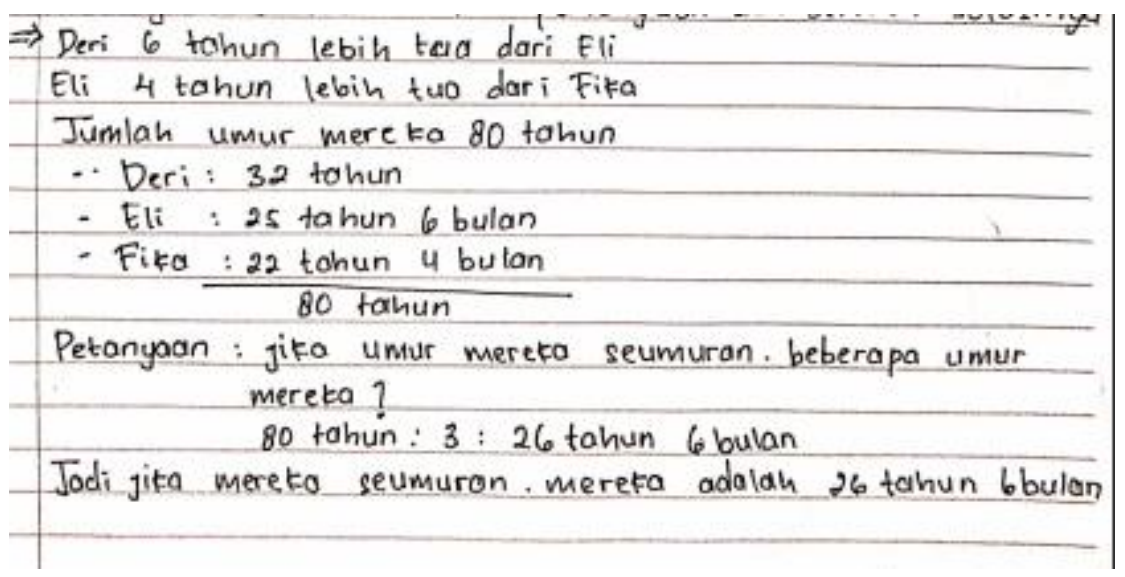

Gambar 5. Hasil Pekerjaan $S_{2}$ Soal Nomor 2

Dari gambar diatas dapat diketahui bahwa $S_{2}$ kurang memahami soal yang diberikan oleh peneliti, terlihat dari jawaban yang diberikan $S_{2}$ masih sedikit kurang tepat. Dalam menjawab pertanyaan no $2, S_{2}$ hanya mengira - ngira dalam menentukan umur masing - masing. Lalu perkiraan umur masing - masing yang $S_{2}$ tentukan di jumlah maka $S_{2}$ dapatkan jumlahnya yaitu 80 . Tetapi setelah dihitung ulang ternyata hasil jumlah dari umur masing - masing yang $S_{2}$ hitung kurang tepat. Setelah itu $S_{2}$ membuat pertanyaan yang menurut $S_{2}$ sedikit mudah untuk menyelesaikannya. Walaupun perhitungan jumlah umur masing - masingnya kurang tepat tapi saat di wawancara $S_{2}$ dapat memahami salahnya dan dapat membenarkan jawabannya. Berikut cuplikan hasil wawancara peneliti dengan $S_{2}$.

$P$ : "Oke, jadi yang umur nya ini kamu ngira ngira ya?"

S: "Iya perkiraan saya"

P: "Tapi kamu paham ga maksud dari soal no 2 ini?"

S: "Kurang paham bu sebenernya, ini saya dapat rumus dari temen saya. Dia mengasih rumus ini dan saya mencoba rumusnya."

P: "Oke, coba liat umur deri sama eli kan bedanya 6 tahun, kalau 32 di kurang 25 tahun 6 bulan hasilnya 6 tahun bukan?"

S: "Oh iya, saya kurang teliti."

P: "Jadi jawabannya yang benar berapa?"

$S:$ " 6 tahun 6 bulan ya bu?"

P: "Iya."

Berdasarkan cuplikan hasil wawancara diatas dapat diketahui bahwa $S_{2}$ kurang memahami soal yang diberikan. Hal tersebut terlihat dari cara $S_{2}$ menjawab pertanyaan hanya dengan cara mengira ngira umur masing - masing kemudiaan perkiraan umurnya di jumlahkan. Tetapi dalam menjumlahkan umurnya $S_{2}$ kurang tepat dalam menghitungnya. Dalam hasil wawancara diatas, $S_{2}$ juga menyebutkan bahwa ia kurang memahami pertanyaannya dan dalam menjawab pertanyaan ia juga mencontoh cara temannya. Hal ini menunjukkan bahwa $S_{2}$ kurang memenuhi aspek fleksibilitas, walaupun $S_{2}$ dapat menggunakan cara lain dalam menyelesaikan masalah yang diberikan tetapi untuk jawabannya kurang 
tepat dan $S_{2}$ juga kurang memahami pertanyaan yang diberikan, ia hanya mengikuti cara yang temannya berikan.

Berdasarkan hasil pekerjaan dan hasil wawancara yang dilakukan maka dapat diketahui bahwa $S_{2}$ kurang memahami pertanyaan yang diberikan. Hal itu terlihat dari cara $S_{2}$ menjawab pertanyaan. Saat menjelaskan jawabannya kepada peneliti, $S_{2}$ juga terlihat sedikit bingung dalam menjelaskan. Walaupun ia mampu menyelesaikan masalah dengan satu cara penyelesaian kemudian dengan cara penyelesaian lain, tetapi jawaban yang ia kerjakan kurang tepat dan ia hanya mengikuti cara yang diberikan oleh temannya. Sehingga dapat dikatakan bahwa $S_{2}$ kurang memenuhi aspek fleksibilitas.

\section{Jawaban nomor 3}

Berikut peneliti sajikan hasil pekerjaan $S_{2}$ dalam mengerjakan pertanyaan no 3 yaitu menentukan panjang pita masing masing yang di ketahui di soal dengan terlebih dahulu menentukan panjang pita seluruhnya.

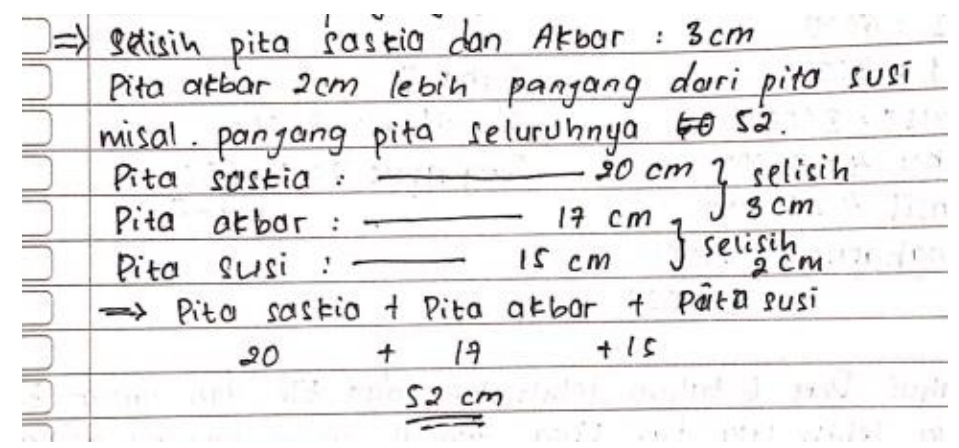

Gambar 6. Hasil Pekerjaan $S_{2}$ Soal Nomor 3

Dari gambar diatas dapat diketahui bahwa $S_{2}$ dapat memahami soal yang diberikan oleh peneliti, karena terlihat dari jawaban siswa yang diberikan sudah benar. $S_{2}$ dapat menjawab pertanyaan dengan caranya sendiri yaitu menentukan terlebih dahulu panjang pita seluruhnya. Setelah itu $S_{2}$ menentukan panjang pita masing - masing dengan cara mengira - ngira panjang pitanya. Dalam menjawab soal, $S_{2}$ menggunakan cara yang berbeda dengan cara pada umumnya. Karena pada nomor 3 ini $S_{2}$ menggunakan cara kira - kira dalam menjawab soal. Jawaban $S_{2}$ juga didukung dengan cuplikan hasil wawancara berikut.

P: "Jadi paham sama soal no 3 ini kan?”

S: "paham, no 2 sedikit rumit."

P: "No 3 ini menurut kamu apakah ada cara lain?"

S: "Menurut saya ini cara yang sedikit mudah."

P: "Dengan perkiraan ya?"

S: "Iya."

P: "Oke, dari soal yang sudah kamu kerjakan ini. Apakah kamu pernah jumpai sebelumnya?"

S: "belum." 


\section{P: "Apakah soal seperti itu belum pernah di ajarkan oleh gurunya?"}

S: "Sepertinya sudah tapi saya saja yang kurang paham sama soal cerita."

Berdasarkan hasil cuplikan wawancara diatas dapat diketahui bahwa $S_{2}$ belum pernah menjumpai soal tersebut sebelumnya. $S_{2}$ menjawab soal sesuai dengan apa yang ada dalam pemikirannya. Hal ini menunjukkan bahwa dari jawaban yang sudah $S_{2}$ kerjakan bahwa $S_{2}$ memenuhi aspek kebaruan (originality).

Berdasarkan hasil pekerjaan dan hasil wawancara yang dilakukan, maka dapat diketahui bahwa $S_{2}$ menjawab soal no 3 dengan caranya sendiri yaitu mengira - ngira panjang pita masing - masingnya. Cara yang digunakan $S_{2}$ juga tidak terkait dengan materi SPLTV, maka dapat dikatakan $S_{2}$ mampu membuat solusi berbeda dari solusi yang sudah ada. Sehingga dapat dikatakan bahwa $S_{2}$ sudah memenuhi kemampuan berpikir kreatif lain yaitu aspek kebaruan (originality).

\section{Subjek ketiga $\left(S_{3}\right)$}

Berdasarkan hasil pengamatan data yang diperoleh dari penelitian, berikut analisis data kemampuan berpikir kreatif $\left(S_{3}\right)$ dalam menyelesaikan masalah sistem persamaan linear tiga variabel.

\section{Jawaban nomor 1}

Berikut peneliti sajikan hasil pekerjaan $S_{3}$ dalam mengerjakan pertanyaan no 1 yaitu mencari kemungkinan jumlah barang yang dibeli sehingga uang abis.

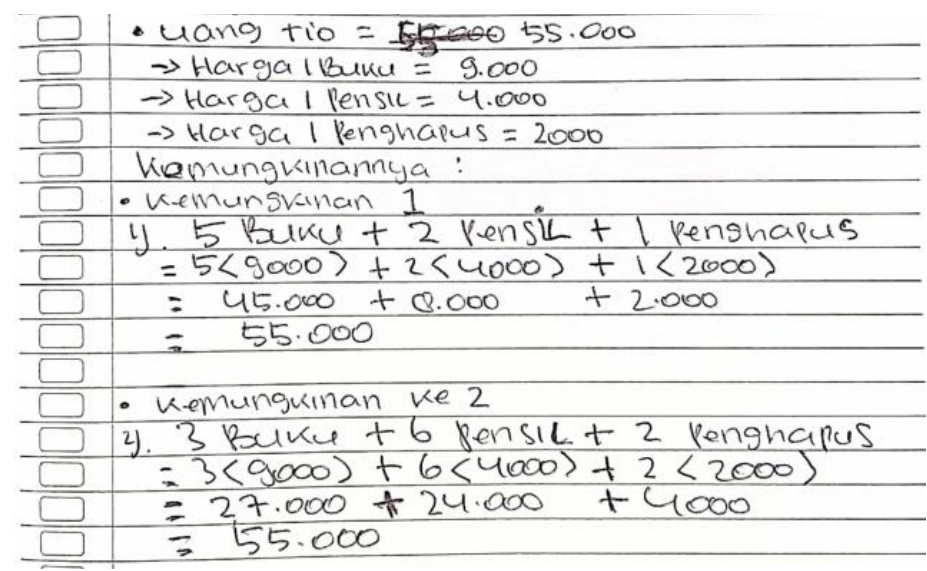

Gambar 7. Hasil pekerjaan $S_{3}$ soal nomor 1

Dari gambar diatas dapat diketahui bahwa $S_{3}$ mampu memahami soal yang diberikan oleh peneliti, karena terlihat dari jawaban $S_{3}$ sudah benar. Dalam menjawab pertanyaan no $1, S_{3}$ menggunakan cara mengira - ngira jumlah buku, pensil dan pengapusnya. Setelah itu jumlah buku, pensil dan penghapusnya dikali dengan harga buku, pensil dan penghapus yang sudah ditentukan disoal. Setelah jumlah buku, pensil dan penghapusnya dikali dengan harga masing-masing. Untuk kemungkinan 1 dan 2, $S_{3}$ menggunakan cara yang sama untuk menjawab soal yang diberikan. Saat diwawancarai $S_{3}$ juga menjelaskan bahwa ia menjawab pertanyaan no 1 dengan cara perkiraan yaitu 
Analisis Kemampuan Berpikir Kreatif Matematis Siswa dalam Menyelesaikan Masalah Sistem Persamaan Linear Tiga Variabel, Ita Triyani, Ervin Azhar

dengan mencoba - coba terlebih dahulu saat menghitung. Berikut cuplikan hasil wawancara antara peneliti dengan $S_{3}$.

P: "Dari jawaban yang kamu kerjakan disini kamu jawab kemungkinan 1 nya itu 5 buku, 2 pensil dan 1 penghapus lalu kemungkinan kedua nya itu 3 buku, 6 pensil dan 2 penghapus itu caranya darimana bisa mendapatakan 2 kemungkinan itu?”

S: "Caranya itu aku pake cara perkiraan kak jadi dicoba coba dulu gitu."

P: "menurut kamu ada cara lain ga untuk no 1 ini?"

S: "kayaknya sih ada deh kak."

Berdasarkan cuplikan wawancara diatas dapat diketahui bahwa $S_{3}$ memahami soal yang diberikan karena terlihat dari cara $S_{3}$ menjawab pertanyaan. Saat di wawancara $S_{3}$ menjelaskan bahwa dalam menjawab soal dia menggunakan perkiraan. $S_{3}$ juga mampu menjelaskan jawabannya dengan lancar saat peneliti meminta $S_{3}$ menjelaskan jawabannya. Selain itu $S_{3}$ juga mampu menemukan kemungkinan jawaban lain dari soal yang diberikan. Hal ini menunjukkan bahwa $S_{3}$ memenuhi aspek kefasihan (fluency) dalam menjawab pertanyaan yang diberikan oleh peneliti.

Berdasarkan hasil pekerjaan dan hasil wawancara yang dilakukan maka dapat diketahui bahwa $S_{3}$ mampu memahami soal yang diberikan oleh peneliti sehingga $S_{3}$ mampu menemukan kemungkinan jawaban lain dari soal yang diberikan. $S_{3}$ juga mampu menjawab soal dengan benar dan lancar menjelaskan jawabannya kepada peneliti saat di wawancara. Sehingga dapat dikatakan bahwa $S_{3}$ sudah memenuhi aspek kefasihan (fluency).

\section{Jawaban nomor 2}

Berikut peneliti sajikan hasil pekerjaan $S_{3}$ dalam mengerjakan pertanyaan nomor 2 yaitu menentukan umur masing - masing dari yang diketahui di soal lalu dari hasil jawaban subjek dibuat soal dan jawabannya.

\begin{tabular}{|c|c|}
\hline$\Longrightarrow$ & edno $=v i+a+5$ \\
\hline$\Longrightarrow$ & Vita $=$ rara +2 \\
\hline & \\
\hline 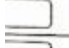 & edho t vita = rara \\
\hline$\Longrightarrow$ & vita $+5+$ viea $=$ edro +2 \\
\hline$\Longrightarrow$ & 2 vita $t 5=($ vita $=5\rangle+2$ \\
\hline$\Longrightarrow$ & 2 vita +5 zita +7 \\
\hline$\Longrightarrow$ & 2vita-vita $=7-5$ \\
\hline 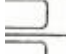 & vita $=2$ tahun \\
\hline$\rightleftharpoons$ & \\
\hline 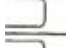 & edno $=$ vita $a 5$ \\
\hline$\Longrightarrow$ & $=2+5=7$ tanun \\
\hline 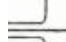 & \\
\hline$\supseteq$ & rara $=$ edno +2 \\
\hline$\supseteq$ & $=7+2=9$ Tanon \\
\hline
\end{tabular}

Gambar 8. Hasil pekerjaan $S_{3}$ soal nomor 2 
Dari gambar diatas dapat diketahui bahwa $S_{3}$ kurang memahami soal yang diberikan oleh peneliti, karena terlihat dari jawaban yang $S_{3}$ kerjakan masih kurang tepat. Dalam menjawab soal no 2, pertama $S_{3}$ membuat persamaan dari yang diketahui di soal. Cara yang di gunakan $S_{3}$ dalam menjawab soal dapat dilihat pada gambar. Walaupun saat mengerjakan soal $S_{3}$ menggunakan cara lain tetapi jawaban $S_{3}$ kurang tepat. Saat diwawancara $S_{3}$ juga mengakui kalau ia tidak yakin sama jawaban yang telah ia kerjakan dan ia juga masih kurang paham dengan perhitungannya. Berikut cuplikan wawancara antara peneliti dan $S_{3}$.

P: "Bisa jelaskan ke saya bagaimana cara kamu mengerjakan no 2 ini?"

$S:$ "Iya, jadi edho $=v i t a+5$, vita $=$ rara +2 , terus edho + vita $=$ rara , vita $+5+$ vita $=$ edho +2 ,

lalu 2 vita $+5=(v i t a+5)+2,2$ vita $+5=$ vita $+7,2$ vita - vita $=7-5$, vita $=2$ tahun. Saya kurang yakin sih kak sama jawaban yang ini."

P: "Jadi saat perhitungannya kamu masih bingung?"

S: "Iya kak, saya susah ngerti."

Berdasarkan cuplikan wawancara diatas dapat diketahui bahwa $S_{3}$ kurang memahami soal yang diberikan dan saat menghitung $S_{3}$ juga susah mengerti cara perhitungannya jadi $S_{3}$ hanya menjawab soal dengan sebisanya. Selain itu $S_{3}$ juga hanya menghitung satu cara atau jawaban yang $S_{3}$ kerjakan belum selesai.

Berdasarkan hasil pekerjaan dan hasil wawancara diatas dapat diketahui bahwa $S_{3}$ kurang memahami soal yang diberikan hal itu terlihat dari jawaban $S_{3}$ dan hasil wawancaranya, karena saat diwawancara $S_{3}$ mengaku bahwa ia susah mengerti dengan cara perhitungannya dan ia juga bingung menjelaskan cara yang ia kerjakan. Selain itu jawaban $S_{3}$ juga masih belum selesai, ia belum membuat soal dari hasil jawabannya. Sehingga dapat dikatakan bahwa $S_{3}$ kurang memenuhi aspek fleksibilitas.

\section{Jawaban nomor 3}

Berikut peneliti sajikan hasil pekerjaan $S_{3}$ dalam mengerjakan pertanyaan no 3 yaitu menentukan panjang pita masing masing yang di ketahui di soal dengan terlebih dahulu menentukan panjang pita seluruhnya.

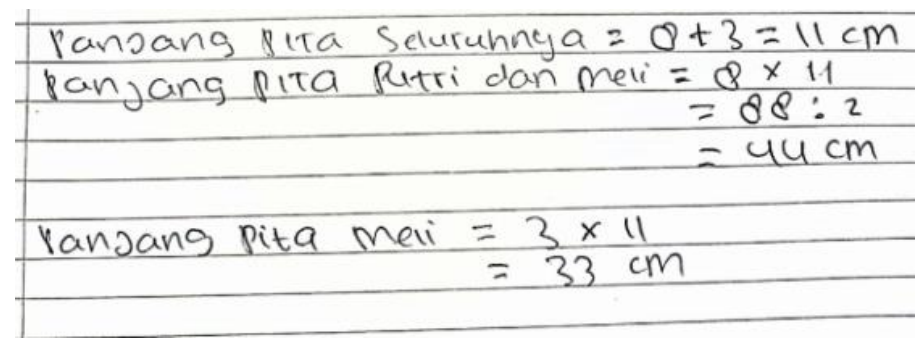

Gambar 9. Hasil Pekerjaan $S_{3}$ Soal Nomor 3

Dari gambar diatas dapat diketahui bahwa $S_{3}$ kurang memahami cara penyelesaian soal tersebut, hal itu terlihat dari cara $S_{3}$ menjawab pertanyaan no 3. Saat menjawab pertanyaan no $3, S_{3}$ hanya 
menjumlahkan angka yang diketahui disoal. Lalu hasilnya dikali dengan angka yang diketahui maka di dapat hasilnya $44 \mathrm{~cm}$ dan $33 \mathrm{~cm}$. Saat di wawancara $S_{3}$ juga menjawab bahwa ia mengerjakan soal no 3 ini dengan cara coba - coba. Berikut cuplikan wawancara antara $S_{3}$ dengan peneliti.

P: "Kamu paham ga maksud dari soal no 3 ini?"

S: "Kalau dari pertanyaan nya sih paham ya kak, cuma kalau menyelesaikan nya itu masih bingung."

P: "Ini kamu mengerjakan $8+3$ itu darimana?"

S: "ehh coba coba aja sih kak, soalnya pas ngerjainnya waktunya udah mepet mau dikumpulin."

P: "Oke, dari no 3 ini menurut kamu apakah ada cara lain?"

S: "Ada, cara eliminasi dan substitusi."

P: "Oke, dari soal yang sudah kamu kerjakan apakah sebelumnya kamu pernah temukan soal seperti ini?"

S: "Pernah, pernah menemukan."

P: "Pernah di ajarin sama gurunya?"

S: “Iya pernah kak, kelas 9 kayaknya."

P: "Jadi jawaban kamu ini hasil pemikiran kamu sendiri atau sebelumnya pernah kamu kerjakan dengan cara yang diajarkan gurunya?"

S: "engga, ini sih awalnya ngerjain ngikutin cara yang udah diajarin itu tapi kayak tiba-tiba bingung gitu kak, kayak ga ketemu jawabannya gitu. Yaudh jadi coba - coba."

Berdasarkan cuplikan wawancara diatas dapat diketahui bahwa $S_{3}$ memahami pertanyaan yang diberikan tetapi masih kurang paham cara menyelesaikannya. $S_{3}$ juga menjelaskan bahwa dalam mengerjakan soal no 3 ini, ia menggunakan cara coba - coba dengan menjumlahkan angka yang diketahui lalu hasilnya dikali dan dibagi dengan angka yang diketahui seperti di gambar. Hal ini menunjukkan bahwa dari jawaban yang sudah $S_{3}$ kerjakan $S_{3}$ kurang memenuhi aspek kebaruan (originality) karena $S_{3}$ belum mampu membuat solusi yang berbeda dengan benar.

Berdasarkan hasil pekerjaan dan hasil wawancara yang dilakukan maka dapat diketahui bahwa $S_{3}$ kurang paham cara menyelesaikan soal no 3 ini. Karena $S_{3}$ hanya menjawab dengan cara mencoba coba angka yang diketahui disoal dan didapatkan hasil jawaban yang kurang tepat. Sehingga dapat dikatakan bahwa $S_{3}$ kurang memenuhi aspek kebaruan (originality).

\section{KESIMPULAN}

Berdasarkan hasil penelitian yang telah di lakukan maka dapat peneliti simpulkan bahwa kemampuan berpikir kreatif siswa dalam menyelesaikan masalah sistem persamaan linear tiga variabel hanya ada satu subjek dari tiga subjek yang di wawancara yang dapat mencapai ketiga aspek kemampuan berpikir kreatif menurut silver yaitu $S_{1}$. Sedangkan $S_{2}$ hanya memenuhi dua aspek kemampuan berpikir kreatif menurut silver yaitu aspek kefasihan dan kebaruan dan $S_{3}$ hanya memenuhi satu aspek kemampuan berpikir kreatif menurut silver yaitu kefasihan. Jadi dapat diketahui bahwa tingkat kefasihan ketiga subjek sangat tinggi, tingkat fleksibilitas ketiga subjek tergolong rendah dan tingkat 
kebaruan ketiga subjek tergolong sedang. Jika dilihat dari 22 siswa yang mengerjakan tes, maka didapatkan kesimpulan kemampuan berpikir kreatif siswa masih rendah karena terlihat dari hasil jawaban siswa ada 12 orang yang memiliki kemampuan berpikir kreatif rendah.

Berdasarkan hal tersebut maka tenaga pendidik harus lebih mengembangkan model pembelajaran agar dapat meningkatkan kemampuan berpikir kreatif siswa, serta guru harus lebih memotivasi siswa agar siswa bisa mengembangkan kemampuan berpikir kreatifnya lebih baik lagi. Untuk peneliti selanjutnya diharapkan dapat melakukan penelitian lanjutan mengenai tingkat kemampuan berpikir kreatif.

\section{REFERENSI}

Amidi, \& Zahid, M. Z. (2016). Membangun Kemampuan Berpikir Kreatif Matematis Dengan Model Pembelajaran Berbasis Masalah Berbantuan E-Learning. Seminar Nasional Matematika X Universitas Negeri Semarang 2016.

AN Saputra. (2020). Kartu Soal (Pilihan Ganda) Mata Pelajaran: Matematika Wajib. Paper Knowledge . Toward a Media History of Documents. http://repository.unpkediri.ac.id/1229/4/RAMA_84202_0002026403_0724077901_07_lamp.pdf

Andiyana, M. A., Maya, R., \& Hidayat, W. (2018). Analisis Kemampuan Berpikir Kreatif Matematis Siswa Smp Pada Materi Bangun Ruang. JPMI (Jurnal Pembelajaran Matematika Inovatif). https://doi.org/10.22460/jpmi.v1i3.p239-248

Cardo A.P., D., Napisah, D., Wungo, D. D., Utama, G. D., \& Ambarawati, M. (2020). Analisis Kesulitan Siswa dalam Mempelajari Sistem Persamaan Linear Tiga Variabel. Laplace : Jurnal Pendidikan Matematika, 3(1), 27-42. https://doi.org/10.31537/laplace.v3i1.311

Fitriarosah, N. (2016). Pengembangan Instrumen Berpikir Kreatif Matematis. Prosiding Seminar Nasional Pendidikan Matematika 2016.

Huliatunisa, Y., Hariyani, L., \& Wibisana, E. (2019). Analisis Kemampuan Berfikir Kreatif Matematis Siswa Dalam Menyelesaikan Soal Pemecahan Masalah. 1(1), 56-65.

Mulyaningsih, T., \& Ratu, N. (2018). Analisis Kemampuan Berpikir Kreatif Siswa Smp Dalam Memecahkan Masalah Matematika Pada Materi Pola Barisan Bilangan. Jurnal Pendidikan Berkarakter, 1(1), 34-41.

Muthaharah, Y. A., Kriswandani, \& Prihatnani, E. (2018). Analisis Kemampuan Berpikir Kreatif Matematis Siswa Smp Dalam Menyelesaikan Soal Bangun Ruang Sisi Datar. Jurnal Mitra Pendidikan (JMP Online).

Patra, G. P. A., \& Pujiastuti, H. (2020). Analisis Kesalahan Siswa Dalam Menyelesaikan Soal Cerita Sistem Persamaan Linear Tiga Variabel. Maju (Jurnal Ilmiah Pendidikan Matematika), 7(2), 174 181.

Pratiwi, I., Yulianti, D., \& Fitrianna, A. Y. (2018). Kemampuan Berpikir Kreatif Matematik Siswa Mts Ditinjau Dari Kemampuan Resiliensi Matematik Siswa. JPMI (Jurnal Pembelajaran Matematika 
Analisis Kemampuan Berpikir Kreatif Matematis Siswa dalam Menyelesaikan Masalah Sistem Persamaan Linear Tiga

Inovatif), 1(2), 171. https://doi.org/10.22460/jpmi.v1i2.p171-184

Prianggono, A. (2010). Analisis Proses Berpikir Kreatif Siswa Sekolah Menengah Kejururuan ( Smk) Dalam Pemecahan Dan Pengajuan Masalah Matematika Pada Materi Persamaan Kuadrat. 133142.

Rachman, A. F., \& Amelia, R. (2020). Siswa Sma Di Kabupaten Bandung Barat Dalam Menyelesaikan Soal Pada Materi Trigonometri. Maju.

Rifa'i, R., Sujana, A., \& Romdonah, I. (2020). Penerapan model pembelajaran treffinger untuk meningkatkan kemampuan berpikir kreatif matematis siswa. Jurnal Analisa. https://doi.org/10.15575/ja.v6i1.4365

Silver, E. A. (1997). Kreativität fördern durch einen unterricht, der reichist and situationen des mathematischen problemlösens und aufgabenerfindens. ZDM - International Journal on Mathematics Education, 29(3), 75-80. https://doi.org/10.1007/s11858-997-0003-x

U.S., S. (n.d.). Peran Berpikir Kreatif Dalam Proses. Jurnal Formatif, 2(3), 248-262. 